Review

\title{
Carbon stocks in miombo woodlands: evidence from over 50
} years

\author{
Medha Bulusu'1,2, Christopher Martius ${ }^{1,3,}{ }^{*}$ and Jessica Clendenning ${ }^{1,4}$
}

Citation: Bulusu, M.; Martius, C.; Clendenning, J. Carbon stocks in miombo woodlands: evidence from over 50 years. Forests 2021, 9, x. https://doi.org/10.3390/xxxxx
1 Center for International Forestry Research, Jalan CIFOR, Situ Gede, Sindang Barang, Bogor 16115, Indonesia; medha.bulusu@posteo.net (M.B.)

2 Current address: Tropical Silviculture and Forest Ecology Burckhardt Institute, University of Göttingen, 37077 Göttingen

3 Current address: Center for International Forestry Research (CIFOR) Germany GmbH, Charles-de-GaulleStrasse 5, 53113 Bonn

4 Visiting Fellow, Department of Geography, National University of Singapore; jessnclen@gmail.com (J.C.)

* Correspondence: c.martius@cgiar.org

\begin{abstract}
Miombo woodlands are extensive dry forest ecosystems in central and southern Africa covering $\approx 2.7$ million $\mathrm{km}^{2}$. Despite their vast expanse and global importance for carbon storage, the long-term carbon stocks and dynamics have been poorly researched. The objective of this paper is to present and summarize the evidence gathered on above- and belowground (root and soil) carbon stocks of miombo woodlands from the 1960s to mid-2018 through a review. We analyzed data to answer: (1) What is the range of aboveground and belowground carbon stocks found in miombo woodlands over the last six decades? (2) Are there differences in carbon stocks based on land-management categories? (3) Does precipitation influence aboveground carbon stocks in old-growth miombo? (4) Do differences in cover type, age and region influence carbon stocks? (5) How does previous land-use affect carbon stocks in re-growth miombo? A literature review protocol was used to identify 56 publications from which quantitative data on aboveground and soil carbon pools were extracted. We found that the mean aboveground carbon stock in old-growth miombo was $30.83 \pm 16.76 \mathrm{Mg} \mathrm{C} \mathrm{ha}^{-1}$ (range 1.48-107.24 $\mathrm{Mg} \mathrm{ha}^{-1}$ ). Old-growth miombo had an average calculated root carbon stock of $16.49 \pm 9.18 \mathrm{Mg} \mathrm{C}^{-1}$ (range $0.8-57.81 \mathrm{Mg} \mathrm{ha}^{-1}$ ). Soil carbon stocks in oldgrowth miombo varied widely, between 8.75 and $134.6 \mathrm{Mg} \mathrm{C} \mathrm{ha-1}^{-1}$ while in re-growth miombo they varied between 10.73 and $52.2 \mathrm{Mg} \mathrm{C} \mathrm{ha-1}^{-1}$. It must be noted these soil data are given only for information; they inconsistently refer to varying soil depths and are thus difficult to interpret. The wide range reported suggests a need for further studies, much more systematic in methods and reporting. Other limitations of the dataset include the lack of systematic sampling and lack of data in some countries, viz. Angola and Democratic Republic of the Congo.
\end{abstract}

Keywords: miombo; carbon stocks; aboveground; belowground; soil organic carbon

\section{Introduction}

Forests are important terrestrial ecosystems and act as carbon sinks with up to $2.4 \pm$ $0.4 \mathrm{Pg} \mathrm{C} \mathrm{yr}^{-1}$ carbon sequestered globally over the last two decades [1]. Despite their numerous benefits, trends in global forest cover show a rapid loss of forests due to land use conversion and degradation. These trends have resulted in a loss of 11 gigatonnes (Gt) of global carbon stocks over the past 25 years alone [2]. While the changes occurring in carbon stocks of tropical moist forests are well documented, the changes occurring in the carbon stocks of tropical dry forests, such as the African miombo woodlands, remain poorly quantified and understood. In an attempt to address this gap, this review synthesizes the current data available on above and below-ground carbon stocks in the miombo 
woodlands to inform the development of appropriate policies to better manage these valuable, but diminishing, ecosystems.

Miombo woodlands are seasonal tropical dry forests found in parts of south and central Africa and extending over Angola, Zimbabwe, Malawi, Mozambique, Tanzania, Zambia and the Democratic Republic of Congo [3]. They are the most extensive dry forest woodlands in all of Africa, covering over 2.7 million $\mathrm{km}^{2}$ [4]. These woodlands are recognized as an ecoregion (a large area of land or water having characteristic species and environmental conditions that is biologically different from other regions) [5]. Miombo woodlands are the largest of 21 ecoregions in sub-Saharan Africa and part of the WWF's (World Wildlife Fund) Global 200 most important ecoregions [5]. The landscape of these woodlands is dominated by trees of the genera Brachystegia, Julbernardia and/or Isoberlinia all belonging to the legume family Fabaceae (subfamily Caesalpinioideae) [4].

Miombo woodlands are often distinguished into two main cover types: old-growth and re-growth. Old-growth woodlands (OG) are relatively mature woodlands with little indication that these were intensively used or logged. Re-growth woodlands (RG) refer to naturally regenerating woodlands following the clearing of mature woodlands for agriculture or other purposes. As the woodlands have supported humans for centuries through the use of fire, timber for charcoal production, and land for cultivation the regrowth category is especially relevant [6]. Since the Caesalpinoid species do not die out after clearing and regenerate easily from existing root systems [5] it is common to find these woodlands in various stages of regrowth. If appropriately managed, these re-growth woodlands can contribute to carbon sequestration [5].

Rainfall, and its effect on vegetation growth, varies significantly in the eco-region. This is why the woodlands are often characterized as either dry or wet [7] based on the mean annual precipitation (MAP). Dry miombo refers to areas receiving less than 1000 $\mathrm{mm}$ rainfall annually with Brachystegia spiciformis, B. boehmii and Julbernardia globiflora as the dominant tree species, while wet miombo areas receive more than $1000 \mathrm{~mm}$ rainfall per year with a comparatively richer floristic composition of Brachystegia floribunda, B. glaberrima, B. longifolia, B. wangermeeana, Julbernardia paniculata, Isoberlinia angolensis and Marquesia macroura [4]. Elevation and MAP range also vary in the region: study sites reported an elevation range of 316-2080m above sea level and a MAP range of 629-1600mm.

Many areas of the miombo are protected for conservation purposes which fall under a broad range of management practices for protected areas. OG are classified according to their legal protection status following IUCN conservation categories of national parks (NP), forest reserves (FR) and game management areas (GMA). When no protected status is reported they are considered as open areas (OA). Accordingly, different types of miombo habitats are covered in the present review, e.g., Katani et al. [8] estimated biomass at upland and lowland miombo sites; while Guedes [9] looked at carbon storage in mountain miombo, a type of miombo forest found at high altitudes (1100-1700m above sea level. The objective of this paper is to present and summarize the evidence gathered on aboveand belowground carbon stocks of miombo woodlands from the 1960s to mid-2018. To be included in the review, studies had to show two main criteria (and further explained below): first, that the study site(s) were in miombo woodlands through the presence of tree species of the genera Brachystegia, Julbernardia and Isoberlinia; and second, the study had to present quantitative data for aboveground and/or belowground (soil) pools. With these data, we discuss the following questions:

1. What is the range of aboveground and belowground carbon stocks found in miombo woodlands over the last six decades?

2. Are there differences in carbon stocks based on land management categories?

3. Does precipitation influence aboveground carbon stock in old-growth miombo?

4. Do differences in cover type (old-growth and re-growth), age of woodland and region influence carbon stocks?

5. Does previous land-use effect carbon stocks in re-growth miombo? 


\section{Materials and Methods}

99

\subsection{Literature review and data extraction}

The aim of this paper was to review evidence on the above- and belowground carbon stocks of miombo woodlands spanning six decades (1960s to mid-2018). Literature was reviewed for the period 2016 to mid-2018 following the systematic review protocol by

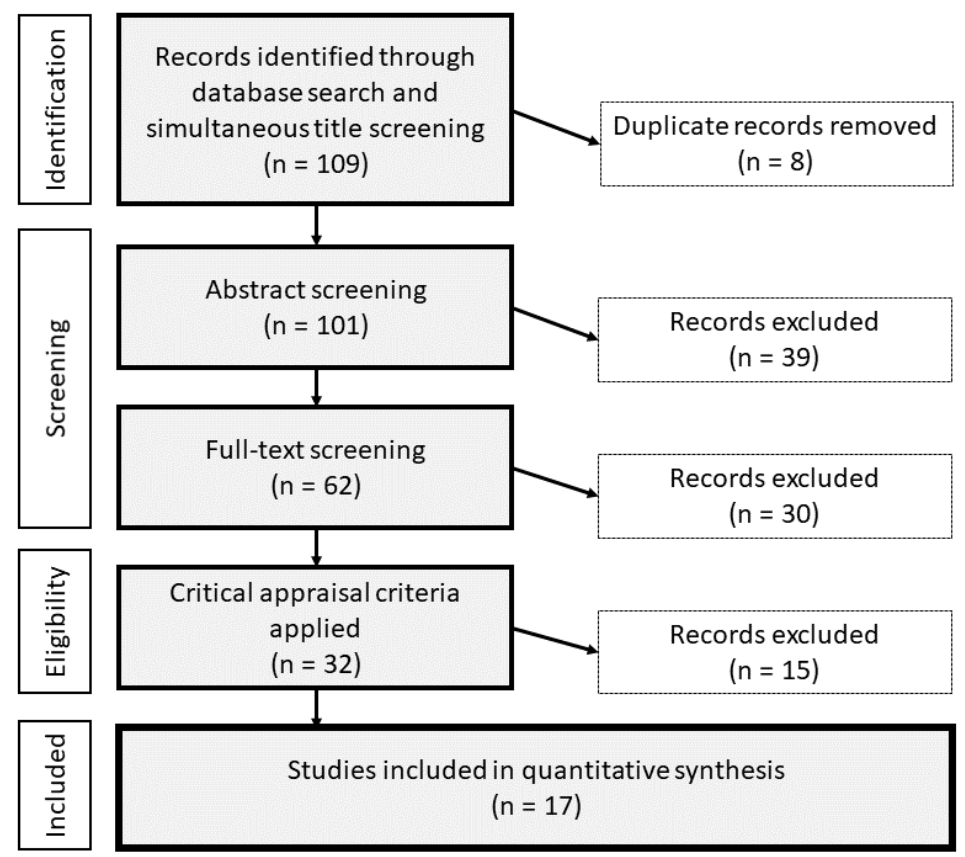

Figure 1. Systematic review process. Graph adapted from [11].

Syampungani et al. [10]. While this study follows a previous systematic review protocol and systematic review methods informed by CIFOR's Evidence-Based Forestry (EBF) initiative $[11,12]$ we emphasize that the present paper is not a 'pure' systematic review. That is, the intention of this paper is to provide a summarized assessment of carbon data for miombo based on the available literature, screened to the best of our knowledge, but falling short of the standard set by EBF (and other systematic review) criteria. In a "pure" systematic review, the references are gathered through a pre-defined search strategy including the time-period [13]. For our paper, we defined the time-period to 2016 to mid-2018. During full-text screening, we found references in the selected studies from before 2016. Here we deviate from the confines of a strict review and added these 'additional' references to the annotated bibliography following the same protocol described above.

After the full text screening (Figure 1), critical appraisal criteria [10] were applied which included study length and duration, relevance of the study area/population (e.g. presence of relevant woodland species), exposures, (e.g. activities which affect aboveand/or belowground carbon stocks such as wood extraction for fuel and charcoal) comparators (e.g. control plots included in study design or before-and-after intervention comparison of study sites) and outcomes (e.g. quantitative data on above and below ground carbon). Questions were also asked regarding the replicability of methods, the clarity and replicability of the analysis, and if the results were logically derived and confounding factors were considered. Additional context-based social and site information were also recorded (such as historical information of study area, ecological context, political context, site characteristics such as climate, soil, seasonality and site vegetation) to further appraise studies. Only those studies with an appraisal rating of medium or high were included, 
while those which were rated low or very low were excluded. a After critical appraisal, 17 papers were selected and data on wood biomass, carbon stocks and soil carbon stocks were extracted into an Excel file (Table S1, Table S2). Other information such as country of study, location, age of study sites, year(s) during which data was collected, geographical coordinates, elevation, mean annual precipitation and miombo type were included in the database. In addition, bibliographic information such as author, year of publication, reference and study type were recorded. Data from the 17 studies were collated with data from 39 quantitative studies from the recently published systematic map by Gumbo et al. [14] for this review. It must be noted that a few references from [14] were excluded due to unverifiable data. The final dataset contains a total of 56 quantitative studies of the best available evidence on the above- and belowground carbon stocks of miombo woodlands. Thus, while the systematic map [14] also informs values for above-ground carbon in oldgrowth miombo woodland, the present study is based on a revised and completed dataset and provides a more in-depth analysis which includes estimates for regrowth miombo and belowground $C$ pools.

By providing a summary of published carbon data as they are currently available, we hope to prompt further, more systematic research into questions regarding the study and documentation of land use, management, and carbon stocks in the miombo woodlands. We also hope this review provides a better basis for calculating forest reference levels for climate research and national climate reporting in sub-Saharan Africa and for institutions such as the UNFCCC (United Nations Framework Convention on Climate Change).

\subsection{Aboveground and belowground carbon stocks}

Data on woody biomass and carbon stocks were recorded into a database. When only basal area estimates were provided they were converted to biomass using the equation from [15]:

Aboveground wood biomass, $\mathrm{y}=0.702 * B A_{b h}-281.484$,

where $\mathrm{y}$ is $\mathrm{kg} \mathrm{ha}^{-1}, \mathrm{BAbh}$ is basal area at breast height (1.3 m aboveground ground) in $\mathrm{cm}^{2}$. Basal area data measured at stump height (between 15 and $30 \mathrm{~cm}$ above ground) were converted to its equivalent at breast height following the equation from [16]:

Basal area $=-0.0019+0.71 *$ stump height basal area,

Biomass data calculated from equation (1) were then converted into $\mathrm{Mg} \mathrm{ha}^{-1}$ by multiplying with 0.001. A carbon conversion factor of 0.47 [17] was used to estimate carbon stocks. Root biomass (RB) was estimated using the root:shoot ratios 0.54 and 0.77 for oldgrowth and re-growth woodland, respectively [15], and subsequently converted into carbon stocks.

\subsection{Soil carbon stocks}

In the assessed literature, soil data were estimated at various depths ranging from 2.5 $\mathrm{cm}$ to $150 \mathrm{~cm}$ belowground and often presented as stratified by soil layers or horizon. However, some studies provided information only on pooled SOC stocks, i.e., for the entire sampling depth considered in the study design rather than stratified by layers $[9,18]$. For these studies, only the total SOC stocks were recorded in the database. It is important to note that not all studies have published error/variation estimates. In addition, there is also a problem of consistency where some studies use standard deviation or standard error of the mean while others use variance estimates. Data on sampling depth and soil

${ }^{a}$ For the appraisal rating, each study was given a score of $1=$ yes, $0.5=$ unclear and $0=$ no for each criterion described above. The values in each row were summed up to obtain an overall rating for each study in the list. The overall rating was categorised as 13-14 = high, $9-12.5=$ medium, $6-8.5=$ low and $0-5.5=$ very low. All studies with low and very low rating were excluded (See TABLE S1 - Study validity, included in the supplementary material). 
organic carbon (SOC) stocks were extracted from the selected literature. For estimating SOC stocks ( $\left.\mathrm{Mg} \mathrm{C} \mathrm{ha-1}^{-1}\right)$ from SOC\% the equation by [19] was used:

$$
S O C=S O C \% * B D * S D,
$$

where SOC\%, soil organic carbon; BD, bulk density, $\mathrm{g} \mathrm{cm}^{-3}$; SD, soil depth, $\mathrm{cm}$. Not all studies reported bulk density (BD) values. For miombo woodlands, soil bulk density (to a depth of $20 \mathrm{~cm}$ ) is found in the range of 1.2 to $1.4 \mathrm{~g} \mathrm{~cm}^{-3}[20,21]$ and an average value of $1.3 \mathrm{~g} \mathrm{~cm}^{-3}$ was used for estimating SOC stocks whenever BD values were not reported. When only soil organic matter (SOM)\% data were reported [22] they were converted to SOC\% using the equation from [23]:

$$
\text { SOC } \%=S O M \% * 0.50,
$$

where SOM\%, soil organic matter.

\subsection{Statistical analysis}

A preliminary analysis on the distribution of the aboveground carbon (AGC) stocks for OG $(n=168)$ and RG $(n=114)$ using the Shapiro-Wilk normality test showed that the data do not conform to a normal distribution (OG: $p=0.940$ and RG: $p=0.873$ ) but are positively skewed at 0.05 significance level. Non-parametric tests Mann-Whitney $(\mathrm{M}-\mathrm{W})$ and Kruskal-Wallis (K-W) ANOVA were used to test for significant differences between AGC groups based on factors such as conservation status, precipitation, cover type, age of miombo, region and previous land-use. When results were significant at the 0.05 level, pairwise comparisons of each pair of groups were done using the M-W test with Bonferroni correction to test which pairs of groups were significantly different to each other. All descriptive and comparative statistics were computed using Origin Pro v. 2018b.

\subsubsection{Conservation status and cover type}

Old-growth miombo sites were classified according to their legal protection status following the IUCN conservation categories of national parks (NP) $(n=8)$, forest reserves $(\mathrm{FR})(\mathrm{n}=97)$, game management areas $(\mathrm{GMA})(\mathrm{n}=1)$ and when no protected status was reported it was considered as open area (OA) $(n=62)$. The OG AGC data was grouped by conservation status and the K-W ANOVA was used to verify if these categories vary with respect to AGC.

The AGC data covers both old-growth $(n=168)$ and re-growth $(n=114)$ cover types. $\mathrm{M}-\mathrm{W}$ test was used to verify if the two groups vary with respect to AGC. Age of RG was recorded when available in the study; usually no age was reported for OG.

\subsubsection{Precipitation gradient and age}

The M-W test was used to determine whether there were significant differences between OG AGC stocks of wet $(n=29)$ and dry $(n=133)$ miombo woodlands. Not all papers in the review provided MAP information of the study sites, hence the sample size was smaller than the total sample size for OG AGC. OG AGC stocks were grouped into five precipitation categories $(550-800 \mathrm{~mm}, \mathrm{n}=6 ; 800-1000 \mathrm{~mm}, \mathrm{n}=28 ; 1000-1200 \mathrm{~mm}, \mathrm{n}=$ $7 ; 1200-1400 \mathrm{~mm}, \mathrm{n}=2$; and $1400-1600 \mathrm{~mm}, \mathrm{n}=2$ ) to represent a precipitation gradient. Some studies reported MAP information as a broad range and the corresponding AGC stocks for these were excluded from this part of the analysis. To test for significant differences between the precipitation categories a K-W ANOVA was used.

The AGC stocks were grouped into six age categories $(0-5, \mathrm{n}=15 ; 6-10, \mathrm{n}=23 ; 11-20$, $\mathrm{n}=33 ; 21-30, \mathrm{n}=20 ; 30-50, \mathrm{n}=11$ and $>50$ years, $\mathrm{n}=172$ ). All plot-level RG C stocks were categorized into age classes and all OG data were grouped in the $>50$ years age class. Differences in $C$ stocks for each age category in the aboveground pool were estimated using the $\mathrm{K}-\mathrm{W}$ test. 


\subsubsection{Previous land-use}

Two land-use types prior to abandonment and following natural regeneration in RG are 'agriculture' and 'woodlands cleared for other purposes'. The agricultural fallows are categorized as 'Postcult' $(n=54)$ and RG on previously cleared land as 'Postclear' $(n=54)$. To test for significant differences between these two groups the M-W test was used.

\subsubsection{Parameters influencing aboveground carbon stocks}

To investigate the influence of age (age), precipitation (prec), cover type and miombo type on AGC (carb), a multiple linear model was fitted with different combinations of the aforementioned covariates. Model selection was done using Akaike's information criterion (AIC). Only covariates with a significant influence on AGC were kept in the model. The models were checked by inspecting the residuals and as previous models violated the assumption of a constant variance, we refit the models using a variance function to model the variance. The models were fit using generalized least squares with R Statistical Software version 3.5.1 [24] and the package 'nlme' version 3.1-137 [25].

\section{Results}

\subsection{Literature review}

The countries covered in the literature sweep were Malawi, Mozambique, Tanzania, Zambia and Zimbabwe. Data were not found for Angola and the Democratic Republic of Congo.

Most studies in the dataset were from Tanzania (36\%), followed by Zambia $(28 \%)$ and Zimbabwe (17\%) (Figure 2a). The quantitative studies included are from 1966 to mid2018 with the majority (67\%) published in the 2010s (Figure 2b). A total of 284 observations for AGC stocks were recorded into the database with 168, 114 and 2 observations for the cover types old-growth, re-growth, and cropland, respectively.

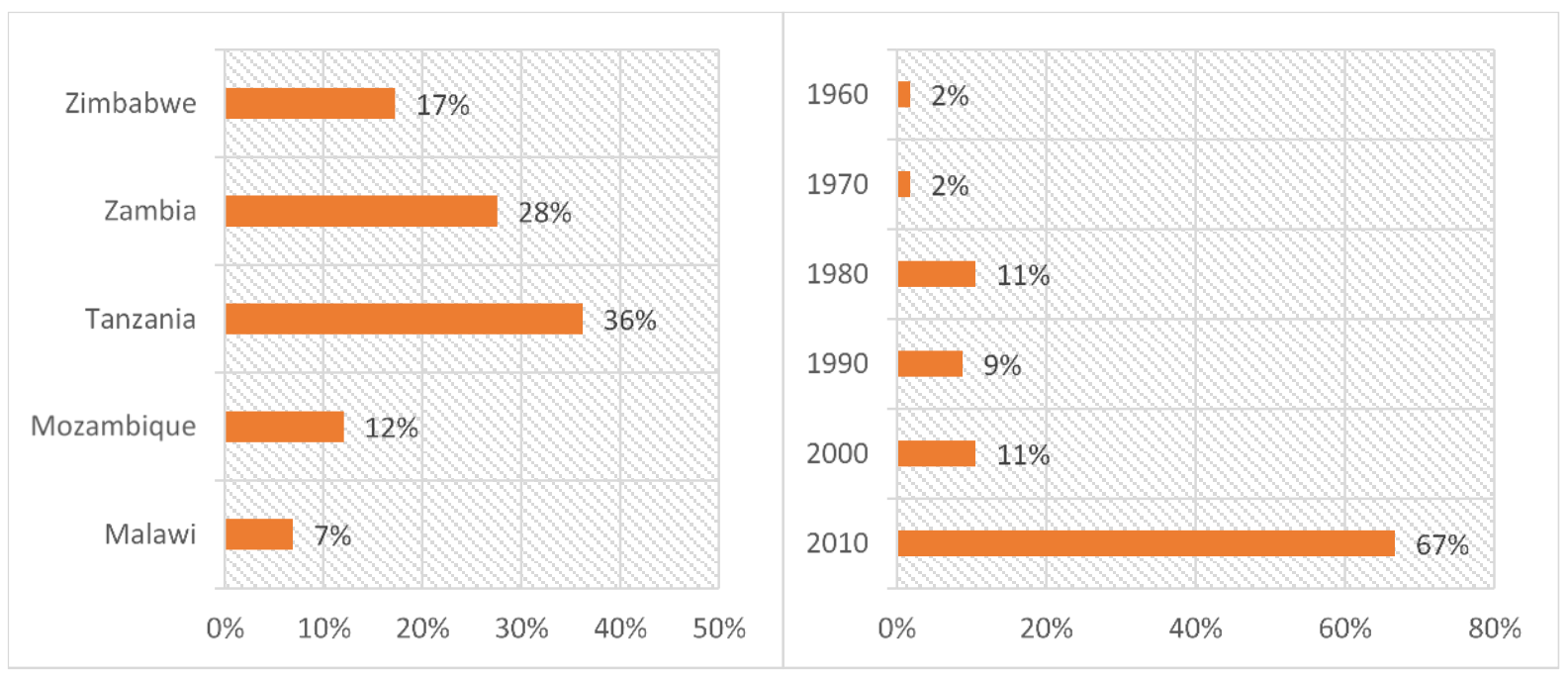

(a)

(b)

Figure 2. Distribution of selected studies by (a) country and (b) publication year.

\subsection{Old-growth above- and belowground carbon stocks}

Data were mainly reported as basal area $\left(\mathrm{m}^{2} \mathrm{ha}^{-1}\right)$, biomass $\left(\mathrm{Mg} \mathrm{ha}^{-1}\right)$, and aboveground carbon stocks ( $\mathrm{Mg} \mathrm{C}^{-1}$ ). Old-growth miombo showed a large variation in the aboveground carbon stocks (Table 1). 
Table 1. Summary statistics for old-growth miombo.

\begin{tabular}{cccccrr}
\hline & \multicolumn{6}{c}{ Summary statistics } \\
\cline { 2 - 7 } & $\mathbf{n}$ & Mean & \multicolumn{1}{c}{ SD } & Min & Median & \multicolumn{1}{c}{ Max } \\
\hline Aboveground carbon & 168 & 30.83 & 16.76 & 1.48 & 29.45 & 107.24 \\
Root carbon & 168 & 16.49 & 9.18 & 0.80 & 15.37 & 57.91 \\
\hline
\end{tabular}

n, sample size; SD, standard deviation.

3.2.1. Case study: Biomass increments in old-growth miombo in Morogoro, Tanzania

Several studies in the database provide longitudinal data on old-growth miombo woodlands from the Kitulangalo Forest Reserve in the Morogoro region of Tanzania. In 1985 , the area was established as a reserve with restrictions on wood harvest which in 1995 was completely protected from any extractive activities [26]. Eight permanent sampling plots were established and measured for biomass density in 1977 by Kielland-Lund [27]. Another study repeated the biomass measurements at the same sites over a period of 15 years [28]. These observations are cited in [26]. Note the case study is in biomass units, not carbon.

When we look at the 15-year period, the plots 1, 3, 5, 4 and 2 showed relative linear above-ground increments of between 2.1 and $2.9 \mathrm{Mg} \mathrm{ha}^{-1}$, while the three remaining plots showed stagnant or declining biomass (-0.7 to $0.1 \mathrm{Mg} \mathrm{ha}^{-1}$ ) (Figure 3). The plots 1, 3, 5, 4 and 2 (following their ranking in Figure 3) which showed increments in biomass at the end of the period, had higher biomass levels in 1977 (39-90 Mg ha-1). In comparison, plots 6,8 and 7 started-out with lower biomass levels $\left(22-46 \mathrm{Mg} \mathrm{ha}^{-1}\right)$ and the levels remained stagnant or even declined at the end of the 15-year period. This case study illustrates (1) that even in miombo sites in the same area biomass can vary widely, and growth rates

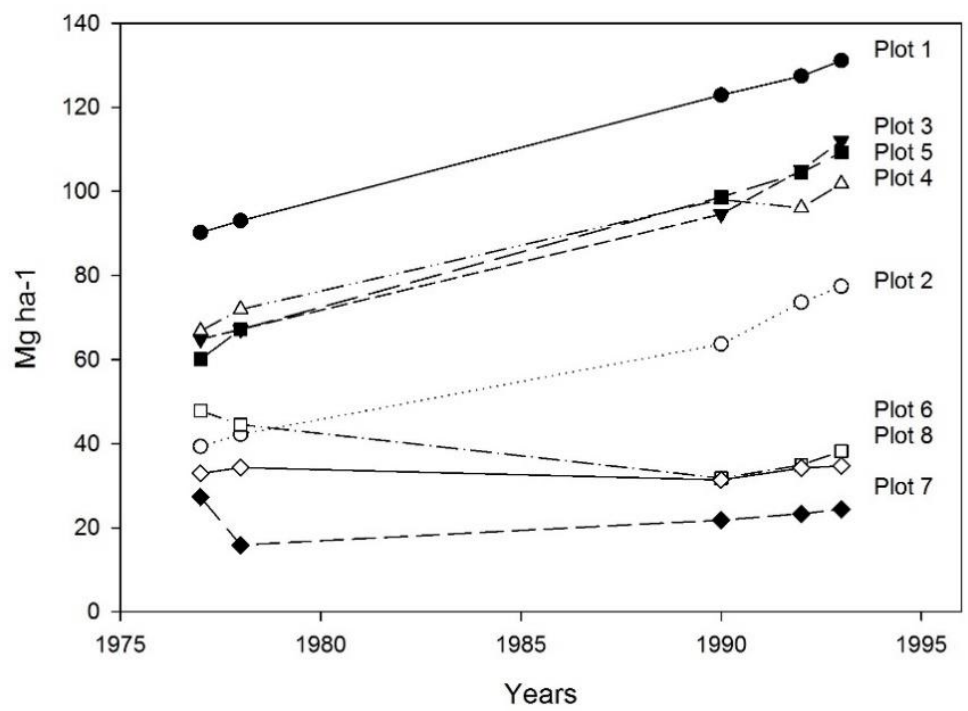

Figure 1/ Variation in old-growth biomass as measured in eight sites in Kitulango Forest Reserve, Tanzania over a period of 15 years. Source: own graph based on data in [27]

vary widely, too; and (2) that the growth rates depend on the initial biomass and may reflect different site-specific conditions.

\subsubsection{Soil carbon stocks}

The SOC stocks of old-growth miombo were reported at varying sapling depths (Table 2). Soil carbon data in re-growth miombo were reported from ages 1 to 30 years since abandonment of the previous land use, i.e., either as fallow land following cultivation or following clearing for other purposes (Table 3) with a minimum of $10.73 \mathrm{Mg} \mathrm{C} \mathrm{ha}^{-1}$ and a maximum of $52.2 \mathrm{Mg} \mathrm{C} \mathrm{ha}^{-1}$. Three of the studies reported soil $\mathrm{C}$ data in agricultural fields 
after clearing of miombo woodlands for conversion into cropland [22,29,30], at varying depths. These ranged between 11.51 Mg C ha-1 and 49.73 $\mathrm{Mg} \mathrm{C} \mathrm{ha}^{-1}$ (Table 4). These sites were continuously cultivated across a varying number of years ranging from 0 to 30 years.

Table 2. Soil organic carbon stocks for old-growth miombo woodlands [9,18,22,29-41.]

\begin{tabular}{|c|c|c|c|c|c|c|c|c|c|c|c|}
\hline $\begin{array}{c}\text { Depth } \\
\text { cm }\end{array}$ & $\begin{array}{l}\text { Soil C } \\
\mathrm{Mg} / \mathrm{ha}\end{array}$ & $\begin{array}{c}\text { Depth } \\
\text { cm }\end{array}$ & $\begin{array}{l}\text { Soil C } \\
\mathrm{Mg} / \mathrm{ha}\end{array}$ & $\begin{array}{c}\text { Depth } \\
\mathrm{cm}\end{array}$ & $\begin{array}{l}\text { Soil C } \\
\mathrm{Mg} / \mathrm{ha}\end{array}$ & $\begin{array}{c}\text { Depth } \\
\mathrm{cm}\end{array}$ & $\begin{array}{l}\text { Soil C } \\
\mathrm{Mg} / \mathrm{ha}\end{array}$ & $\begin{array}{c}\text { Depth } \\
\text { cm }\end{array}$ & $\begin{array}{l}\text { Soil C } \\
\mathrm{Mg} / \mathrm{ha}\end{array}$ & $\begin{array}{c}\text { Depth } \\
\text { cm }\end{array}$ & $\begin{array}{l}\text { Soil C } \\
\mathrm{Mg} / \mathrm{ha}\end{array}$ \\
\hline $0-5$ & 8.75 & $0-15$ & 28.47 & $0-16$ & 19.40 & $0-20$ & 54.10 & $0-25$ & 25.00 & $0-30$ & 14.51 \\
\hline \multirow[t]{11}{*}{$0-5$} & 12.10 & $0-15$ & 45.63 & & & $0-20$ & 30.90 & & & $0-30$ & 14.33 \\
\hline & & $0-15$ & 16.19 & & & $0-20$ & 36.50 & & & $0-30$ & 13.70 \\
\hline & & $0-15$ & 15.41 & & & $0-20$ & 21.06 & & & $0-30$ & 14.66 \\
\hline & & $0-15$ & 14.63 & & & $0-20$ & 21.32 & & & $0-30$ & 34.52 \\
\hline & & $0-15$ & 18.35 & & & $0-20$ & 47.32 & & & $0-30$ & 46.80 \\
\hline & & & & & & $0-20$ & 28.90 & & & $0-30$ & 27.11 \\
\hline & & & & & & & & & & $0-30$ & 28.08 \\
\hline & & & & & & & & & & $0-30$ & 20.20 \\
\hline & & & & & & & & & & $0-30$ & 40.10 \\
\hline & & & & & & & & & & $0-30$ & 29.25 \\
\hline & & & & & & & & & & $0-30$ & 43.88 \\
\hline $\begin{array}{c}\text { Depth } \\
\text { cm }\end{array}$ & $\begin{array}{l}\text { Soil C } \\
\mathrm{Mg} / \mathrm{ha}\end{array}$ & $\begin{array}{c}\text { Depth } \\
\text { cm }\end{array}$ & $\begin{array}{l}\text { Soil C } \\
\mathrm{Mg} / \mathrm{ha}\end{array}$ & $\begin{array}{c}\text { Depth } \\
\text { cm }\end{array}$ & $\begin{array}{l}\text { Soil C } \\
\mathrm{Mg} / \mathrm{ha}\end{array}$ & $\begin{array}{c}\text { Depth } \\
\text { cm }\end{array}$ & $\begin{array}{l}\text { Soil C } \\
\mathrm{Mg} / \mathrm{ha}\end{array}$ & $\begin{array}{l}\text { Depth } \\
\text { cm }\end{array}$ & $\begin{array}{l}\text { Soil C } \\
\mathrm{Mg} / \mathrm{ha}\end{array}$ & $\begin{array}{l}\text { Depth } \\
\text { cm }\end{array}$ & $\begin{array}{l}\text { Soil C } \\
\mathrm{Mg} / \mathrm{ha}\end{array}$ \\
\hline \multirow[t]{4}{*}{$0-35$} & 55.70 & $0-40$ & 45.30 & $0-45$ & 45.60 & $0-50$ & 87.00 & $0-60$ & 134.60 & $0-100$ & 72.47 \\
\hline & & & & & & $0-50$ & 76.30 & $0-60$ & 33.90 & $0-150$ & 82.52 \\
\hline & & & & & & $0-50$ & 34.90 & $0-60$ & 80.10 & & \\
\hline & & & & & & & & $0-60$ & 71.80 & & \\
\hline
\end{tabular}

Table 3. Soil organic carbon stocks in re-growth miombo woodlands as various stages of recovery ranging from 1 to 30 years since abandonment $[21,22,30,42,43$.]

\begin{tabular}{|c|c|c|c|c|c|c|c|c|c|c|c|}
\hline $\begin{array}{c}\text { Depth } \\
\text { cm }\end{array}$ & $\begin{array}{c}\text { Age } \\
\text { yr }\end{array}$ & $\begin{array}{l}\text { Soil C } \\
\text { Mg/ha }\end{array}$ & $\begin{array}{c}\text { Depth } \\
\text { cm }\end{array}$ & $\begin{array}{c}\text { Age } \\
\text { yr }\end{array}$ & $\begin{array}{l}\text { Soil C } \\
\mathrm{Mg} / \mathrm{ha}\end{array}$ & $\begin{array}{c}\text { Depth } \\
\text { cm }\end{array}$ & $\begin{array}{c}\text { Age } \\
\text { yr }\end{array}$ & $\begin{array}{l}\text { Soil C } \\
\mathrm{Mg} / \mathrm{ha}\end{array}$ & $\begin{array}{c}\text { Depth } \\
\text { cm }\end{array}$ & $\begin{array}{c}\text { Age } \\
\text { yr }\end{array}$ & $\begin{array}{l}\text { Soil C } \\
\text { Mg/ha }\end{array}$ \\
\hline $0-15$ & 1 & 20.38 & $0-20$ & 16 & 32.76 & $0-30$ & 1 & 24.18 & $0-150$ & $\mathrm{M}$ & 52.2 \\
\hline $0-15$ & 1 & 20.30 & $0-20$ & 16 & 26.26 & $0-30$ & 1 & 42.32 & & & \\
\hline $0-15$ & 1 & 19.70 & & & & $0-30$ & 2 & 13.85 & & & \\
\hline $0-15$ & 1 & 14.70 & & & & $0-30$ & 2 & 18.72 & & & \\
\hline $0-15$ & 1 & 13.00 & & & & $0-30$ & 5 & 23.99 & & & \\
\hline $0-15$ & 2 & 20.87 & & & & $0-30$ & 5 & 35.10 & & & \\
\hline $0-15$ & 2 & 19.17 & & & & $0-30$ & 6 & 25.55 & & & \\
\hline $0-15$ & 2 & 21.26 & & & & $0-30$ & 6 & 10.73 & & & \\
\hline $0-15$ & 2 & 15.91 & & & & $0-30$ & 7 & 19.50 & & & \\
\hline $0-15$ & 2 & 13.82 & & & & $0-30$ & 13 & 24.77 & & & \\
\hline $0-15$ & 3 & 21.22 & & & & $0-30$ & 19 & 29.45 & & & \\
\hline $0-15$ & 3 & 20.21 & & & & $0-30$ & 20 & 34.32 & & & \\
\hline $0-15$ & 4 & 19.85 & & & & $0-30$ & 25 & 24.57 & & & \\
\hline $0-15$ & 20 & 20.50 & & & & $0-30$ & $1-30$ & 45.20 & & & \\
\hline $0-15$ & 20 & 22.50 & & & & & & & & & \\
\hline
\end{tabular}

M, data not reported.

There is a need to emphasize, however, the limitations to interpreting these data due to the variation in the soil depths. Other factors such as variation in the edaphic and climatic conditions, or differences in spatial and temporal dimensions of the data further contribute to the limitations. Although soil C stocks in re-growth are reported at varying ages of natural regeneration, the high variability in the data (Table 3) and the fact that these are reported at differing depths prevents further analyses such as looking at variation in soil $\mathrm{C}$ with age and/or exploring time trends. Similarly, it is difficult to interpret the soil $\mathrm{C}$ data in re-growth miombo woodlands, due to these differences and the changing but mostly unknown site histories. 
Table 4. Soil carbon stocks in cropland following clearing of miombo woodlands [22,29,30.]

\begin{tabular}{|c|c|c|c|c|c|c|c|c|}
\hline Depth, cm & Age, yr & Soil C, Mg C/ha & Depth, cm & Age, yr & Soil C, Mg C/ha & Depth, cm & Age, yr & Soil C, Mg C/ha \\
\hline \multirow[t]{10}{*}{$0-15$} & $\mathrm{M}$ & 45.05 & $0-30$ & 0 & 11.51 & $0-150$ & $1-30$ & 48.35 \\
\hline & & & $0-30$ & 1 & 49.73 & & & \\
\hline & & & $0-30$ & 3 & 23.79 & & & \\
\hline & & & $0-30$ & 4 & 32.18 & & & \\
\hline & & & $0-30$ & 5 & 20.48 & & & \\
\hline & & & $0-30$ & 5 & 24.77 & & & \\
\hline & & & $0-30$ & 7 & 15.80 & & & \\
\hline & & & $0-30$ & 8 & 30.03 & & & \\
\hline & & & $0-30$ & 12 & 11.70 & & & \\
\hline & & & $0-30$ & 14 & 13.26 & & & \\
\hline
\end{tabular}

M, data not reported.

\subsection{Conservation status and cover type}

Results show that AGC in open areas (OA) ranged from $1.48 \mathrm{Mg}$ ha-1 $^{-1}$ to $75.42 \mathrm{Mg}$ ha1, in forest reserves (FR) from $7.47 \mathrm{Mg} \mathrm{ha}^{-1}$ to $107.25 \mathrm{Mg} \mathrm{ha}^{-1}$, and in national parks (NP) from $5.91 \mathrm{Mg} \mathrm{ha}^{-1}$ to $46.48 \mathrm{Mg} \mathrm{ha}^{-1}$. There was only one reported observation for the game management area (GMA) of $23.88 \mathrm{Mg} \mathrm{ha}^{-1}$. There were no significant differences in carbon storage between conservation categories of old-growth miombo sites (K-W ANOVA: $\mathrm{p}=$ $\left.5.85^{-11}\right)$.

Aboveground carbon stock in old-growth miombo ranged from 1.48 to $107.25 \mathrm{Mg}$ ha${ }^{1}$ and in re-growth miombo from 0.09 to $77.07 \mathrm{Mg} \mathrm{ha}^{-1}$. Significant differences in AGC were observed between these two cover types (M-W: $\left.\mathrm{p}=5.848^{-11}\right)$.

\subsection{Precipitation and age}

Wet miombo had a minimum AGC stock of $10.6 \mathrm{Mg}^{-1}$ and a maximum of $75.42 \mathrm{Mg}$ $\mathrm{ha}^{-1}$ with a median value of $38.03 \mathrm{Mg} \mathrm{ha}^{-1}$. The corresponding values for dry miombo are 1.48 $\mathrm{Mg} \mathrm{ha}^{-1}, 107.25 \mathrm{Mg} \mathrm{ha}^{-1}$ and $23.88 \mathrm{Mg} \mathrm{ha}^{-1}$, respectively. AGC stocks differed significantly between the two rainfall categories (M-W: $\mathrm{p}=7.80 \mathrm{E}-08$ ). Differences in carbon storage across a precipitation gradient were calculated using plot-level data from the review (K-W ANOVA: $\mathrm{p}=0.005$ ) and found to be significantly different at the 0.05 level. Using the $\mathrm{M}-\mathrm{W}$ test with a Bonferroni correction $(\mathrm{p}<0.01)$ revealed that there were significant differences between the precipitation categories $550-800 \mathrm{~mm}$ and $1000-1200 \mathrm{~mm}(\mathrm{p}=$ $0.008)$, and between $800-1000 \mathrm{~mm}$ and $1000-1200 \mathrm{~mm}(\mathrm{p}=0.001)$.

Carbon storage also differed significantly across different age classes (K-W ANOVA: $p=8.19 \mathrm{E}-15)$. Pairwise comparisons between the age classes based on the $\mathrm{M}-\mathrm{W}$ test along with a Bonferroni correction revealed that groups differed significantly to each other except for the groups $0-5$ and $6-10$ years and $6-10$ and $21-30$ and $11-20$ and $21-30$ and $30-50$ and $>50$.

\subsection{Previous land-use}

The AGC range was higher for the 'Postclear' category of re-growth category ranging between 3.17 $\mathrm{Mg} \mathrm{ha}^{-1}$ and $77.07 \mathrm{Mg} \mathrm{ha}^{-1}$ than in 'Postcult' category ranging between 0.09 $\mathrm{Mg} \mathrm{ha}^{-1}$ and $61.70 \mathrm{Mg} \mathrm{ha}^{-1}$. AGC storage was significantly different between these two groups $\left(\mathrm{M}-\mathrm{W}: \mathrm{p}=2.41^{-7}\right)$. In general, the AGC stocks increased with age of re-growth fallow (Figure 4). 


\section{Regrowth miombo}

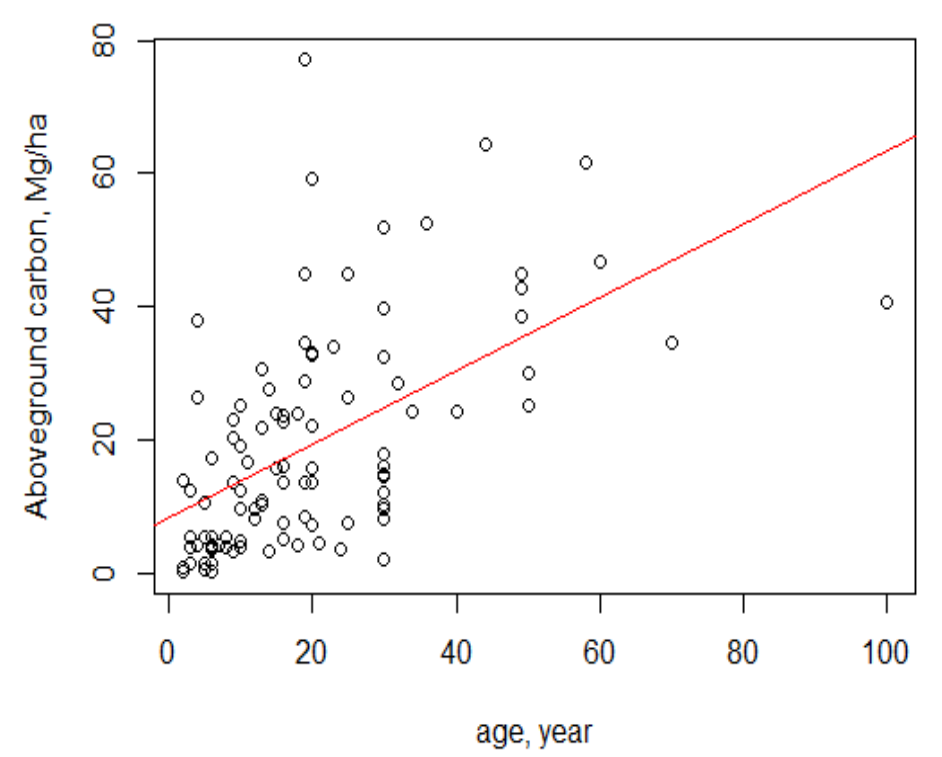

Figure 4. Distribution of aboveground carbon stocks in re-growth miombo by age.

\subsection{Paramters influencing aboveground carbon stocks}

The AGC data of both old-growth and re-growth miombo were used to fit a multiple linear model with different combinations of covariates. The final model selected has age and precipitation as predictors (Table 5). The other covariates cover type (old-growth and re-growth) and miombo type (wet and dry) did not show a significant influence on carbon. The model shows that aboveground carbon increases with age and precipitation (Figure 5).

Table 5. Multiple linear model parameters.

\begin{tabular}{cccc}
\hline & \multicolumn{3}{c}{ Effect on aboveground carbon stocks } \\
\cline { 2 - 4 } & Estimate & SE & p-value \\
\hline Intercept & -15.634545 & 2.8278490 & $<0.01$ \\
Age & 0.690509 & 0.0497392 & $<0.01$ \\
Precipitation & 0.018066 & 0.0033369 & $<0.01$ \\
\hline
\end{tabular}

SE, standard error.

\section{Discussion}

This review demonstrates the little evidence available for the biomass and carbon stocks in above- and belowground pools for the miombo ecoregion in earlier decades. It is only in recent years (from the 2010s onwards) that the evidence base has considerably expanded, accounting for nearly $70 \%$ of the studies in this review. The regional coverage has however not changed and is restricted to the countries of Malawi, Mozambique, Tanzania, Zambia and Zimbabwe. There is still a lack of evidence on biomass and carbon stocks from other key miombo regions such as Angola and the Democratic Republic of Congo. 


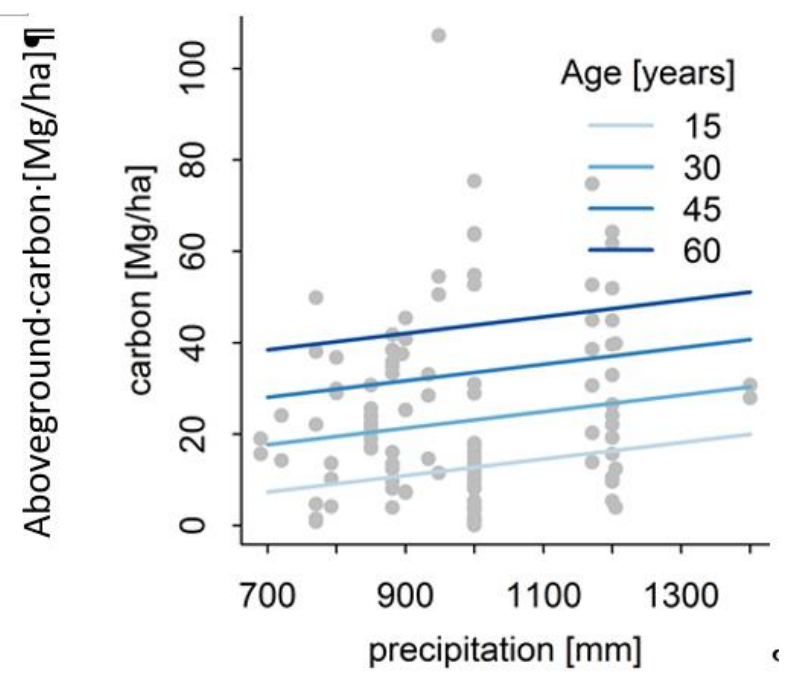

Figure 5. Effect of precipitation and age on aboveground carbon stocks in miombo woodlands.

Data for AGC in dry miombo had a much higher maximum (107.25 $\left.\mathrm{Mg} \mathrm{ha}^{-1}\right)$ than in

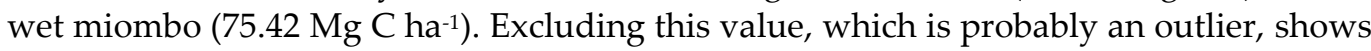
that wet miombo has a higher range of carbon stocks than dry miombo, with ranges 10.6 $-75.42 \mathrm{Mg} \mathrm{ha}^{-1}$ and $1.48-61.62 \mathrm{Mg} \mathrm{ha}^{-1}$, respectively, and a clear difference in the medians, with $38.03 \mathrm{Mg}$ ha-1 $^{-1}$ or wet miombo vs. $23.88 \mathrm{Mg}^{-1} \mathrm{f}^{-1}$ for dry miombo. While wet miombo has a higher AGC range, the values are comparable which suggest that in addition to rainfall there are other factors, such as species composition and variable growth conditions [44], which could also influence carbon storage.

Soil C presents a lesser studied but important carbon pool in the miombo ecoregion. Studies show that the SOC stocks in miombo forests account for significant amounts of total $C$ stored in the ecosystem, storing up to $50-80 \%$ of total $C[9,30]$. The ranges for regrowth and cropland SOC stocks indicate that the two datasets cover a similar range of underlying variability. This could be explained by the similar age range that the data cover, i.e., between $0-30$ years, and most of the data in the re-growth cover type fall under the post-cultivation category. Hence, prior to abandonment most re-growth areas were cultivated. Thus, the similarity in variability of SOC stocks of the two cover types may be attributed the similar land-use management histories. The minimum SOC stock in oldgrowth miombo also falls under a similar range as re-growth and cropland, but oldgrowth miombo stores up to 2.5 times more $C$ on the upper end of the scale.

Miombo woodlands across the region are found in various stages of disturbance from human activities, such as, e.g., selective wood harvesting for charcoal production, leading to changes in wood species structure and diversity. Often, these extractive activities modify the ecosystem to an extent that makes it vulnerable for further degradation. Selective removal of fire-resistant woody species leads to a higher vulnerability of the ecosystem towards fire (which is a naturally occurring event in this region), with consequences for the entire system, e.g., transformation to grassland. Muposhi et al. [45] studied the effects of anthropogenic disturbances on the edges of protected areas along a disturbance gradient with increasing distance from the edge of the park boundary to inside to the park. They found that these disturbances significantly affected wood plant density and height, which is likely to affect the carbon storage of these woodlands. Therefore, there is an urgent need to manage these boundary areas which act as a buffer between communities living outside these protected areas and the protected areas themselves. Introducing buffer zones and extractive reserves to limit the encroachment and degradation of woodlands in these protected areas are some potential possibilities for woodland management.

\section{Conclusion}

Despite the ecological and social importance of miombo woodlands, the carbon stocks of these ecosystems remain poorly assessed and documented which limits the 
scope of any analysis. The variability in aboveground carbon data reported points to stand age and environmental effects but these factors are not consistently recorded across the studies. Root carbon data are missing and could only be inferred from conversion factors, which is not optimal. Soil carbon stocks cannot be reliably computed because different studies sampled widely different soil depths, often pooling the data. Establishing permanent sampling plots with systematic records of environmental parameters and disturbance regimes and levels would be needed in order to assess the time trends in carbon stocks in these woodlands. Moreover, future studies should include sites in the miombo woodlands of Angola and the Democratic Republic of Congo, whose ecosystems and carbon dynamics are absent in the available literature.

Supplementary Materials: The following are available online at www.mdpi.com/xxx/, Additional file 1: Literature search sources and search strings used, Table S1: Study validity, Table S2: References from 2016 to 2018 literature review, Table S3: Selected quantitative studies from the systematic evidence gap map by Gumbo et al. 2018 [14], Table S4: Literature review reference list

\begin{abstract}
Author Contributions: Conceptualization, methodology M.B. and C.M.; formal analysis, M.B.; data curation, M.B. and J.C.; writing - original draft preparation, M.B.; writing-review and editing, C.M.; visualization, M.B. and C.M.; supervision, C.M.; and funding acquisition, C.M.
\end{abstract}

Funding: This research was funded by the CGIAR Research Program on Forests, Trees and Agroforestry (CRP-FTA) with financial support from the CGIAR Fund Donors.

Acknowledgments: We would like to acknowledge the kind assistance with data provided by Emmanuel N. Chidumayo and the other co-authors in the previous studies $[10,14]$.

Conflicts of Interest: The authors declare no conflict of interest. The funders had no role in the design of the study; in the collection, analyses, or interpretation of data; in the writing of the manuscript, or in the decision to publish the results.

\title{
References
}

1. Pan, Y.; Birdsey, R.A.; Fang, J.; Houghton, R.; Kauppi, P.E.; Kurz, W.A.; Phillips, O.L.; Shvidenko, A.; Lewis, S.L.; Canadell, J.G.; et al. A Large and Persistent Carbon Sink in the World's Forests. Science 2011, 333, 988, doi:10.1126/science.1201609.

2. Food and Agriculture Organization of the United Nations. Global forest resources assessment 2015: how are the world's forests changing?, 2015.

3. Campbell, B.M.; Angelsen, A.; Cunningham, A.; Katerere, Y.; Sitoe, A.; Wunder, S. Miombo woodlands - opportunities and barriers to sustainable forest management, 2007.

4. Frost, P. The ecology of miombo woodlands, 1996.

5. Timberlake, J.; Chidumayo, E. Miombo Ecoregion Vision Report; Occasional Publications in Biodiversity No. $20,2011$.

6. Lawton, R.M. A Study of the Dynamic Ecology of Zambian Vegetation. J Ecol 1978, 66, 175-198.

7. White, F. The Vegetation of Africa. A descriptive memoir to accompany the Unesco/AETFAT/UNSO vegetation map of Africa; Unesco: Paris, 1983, ISBN 9789231019555.

8. Katani, J.Z.; Mustalahti, I.; Mukama, K.; Zahabu, E. Participatory forest carbon assessment in south-eastern Tanzania: experiences, costs and implications for REDD+ initiatives. Oryx 2016, 50, 523-532, doi:10.1017/S0030605315000174.

9. Guedes, B. Impacts of Pine and Eucalyptus Plantations on Carbon and Nutrients Stocks and Fluxes in Miombo Forests Ecosystems. Licentiate Thesis; Swedish University of Agricultural Sciences, Uppsala, 2016.

10. Syampungani, S.; Clendenning, J.; Gumbo, D.; Nasi, R.; Moombe, K.; Chirwa, P.; Ribeiro, N.; Grundy, I.; Matakala, N.; Martius, C.; et al. The impact of land use and cover change on above and below-ground carbon stocks of the miombo woodlands since the 1950s: a systematic review protocol. Environ Evid 2014, 3, doi:10.1186/2047-2382-325.

11. Center for International Forestry Research. Evidence-Based Forestry. https://www2.cifor.org/ebf (accessed on 6 April 2020).

12. Petrokofsky, G.; Holmgren, P.; Brown, N. Reliable forest carbon monitoring - systematic reviews as a tool for validating the knowledge base. International Forestry Review 2011, 13, 56-66, doi:10.1505/ifor.13.1.56. 
13. Khan, K.S.; Kunz, R.; Kleijnen, J.; Antes, G. Five steps to conducting a systematic review. J. R. Soc. Med. 2003, 96, 118-121, doi:10.1258/jrsm.96.3.118.

14. Gumbo, D.; Clendenning, J.; Martius, C.; Moombe, K.; Grundy, I.; Nasi, R.; Mumba, K.Y.; Ribeiro, N.; Kabwe, G.; Petrokofsky, G. How have carbon stocks in central and southern Africa's miombo woodlands changed over the last 50 years? A systematic map of the evidence. Environ Evid 2018, 7, doi:10.1186/s13750-018-0128-0.

15. Chidumayo, E.N. Estimating tree biomass and changes in root biomass following clear-cutting of BrachystegiaJulbernardia (miombo) woodland in central Zambia. Envir. Conserv. 2013, 41, 54-63, doi:10.1017/S0376892913000210.

16. Timberlake, J.; Chidumayo, E.; Sawadogo, L. Distribution and Characteristics of African Dry Forests and Woodlands. In The dry forests and woodlands of Africa: Managing for products and services; Chidumayo, E.N., Gumbo, D.J., Eds.; Earthscan: London, Washington DC, 2010; pp 11-42.

17. Chidumayo, E.N. Responses of miombo to harvesting: ecology and management; Stockholm Environment Institute: Stockholm, Sweden, 1993, ISBN 9789188116772.

18. Rossi, J.; Govaerts, A.; Vos, B. de; Verbist, B.; Vervoort, A.; Poesen, J.; Muys, B.; Deckers, J. Spatial structures of soil organic carbon in tropical forests-A case study of Southeastern Tanzania. CATENA 2009, 77, 19-27, doi:10.1016/j.catena.2008.12.003.

19. Pearson, T.; Sarah, W.; Brown, S. Sourcebook for Land Use, Land Use Change and Forestry Projects.; Winrock International, 2005.

20. Chidumayo, E.N.; Kwibisa, L. Effects of deforestation on grass biomass and soil nutrient status in miombo woodland, Zambia. Agriculture, Ecosystems \& Environment 2003, 96, 97-105, doi:10.1016/S0167-8809(02)00229-3.

21. Williams, M.; Ryan, C.M.; Rees, R.M.; Sambane, E.; Fernando, J.; Grace, J. Carbon sequestration and biodiversity of re-growing miombo woodlands in Mozambique. Forest Ecology and Management 2008, 254, 145-155, doi:10.1016/j.foreco.2007.07.033.

22. Kwibisa, L. The effects of indigenous cultivation practices on the recovery of dry miombo woodlands in Central Zambia. MSc. Dissertation; University of Zambia, Zambia, 2000.

23. Pribyl, D.W. A critical review of the conventional SOC to SOM conversion factor. Geoderma 2010, 156, 75-83, doi:10.1016/j.geoderma.2010.02.003.

24. R Core Team. R: A language and environment for statistical computing. R Foundation for Statistical Computing; R Foundation for Statistical Computing: Vienna, Austria, 2018.

25. Pinheiro, J.; Bates, D.; DebRoy, S.; Sarkar, D.; R Core Team. nlme: Linear and Nonlinear Mixed Effects Models. R package version 3.1-137, 2018.

26. Hofstad, O.; Araya, M.M. Optimal wood harvest in miombo woodland considering REDD+payments - A case study at Kitulangalo Forest Reserve, Tanzania. Forest Policy and Economics 2015, 51, 9-16.

27. Kielland-Lund, J. Structure andmorphology of four forest and woodland communities of the Morogoro area, Tanzania. In Struktur und Dynamik von Wäldern Berichte der Internationalen Symposien der Internlationalen Vereinigung für Vegetationskunde (April 13-16, 1981); Dierschke, H., Ed.; Vaduz, 1982; pp 69-93.

28. Ek, T.M. Biomass Structure in Miombo Woodland and Semievergreen Forest. MSc thesis; Norwegian University of Life Sciences, 1994.

29. Mapanda, F.; Mupini, J.; Wuta, M.; Nyamangara, J.; Rees, R.M. A cross-ecosystem assessment of the effects of land cover and land use on soil emission of selected greenhouse gases and related soil properties in Zimbabwe. European Journal of Soil Science 2010, 61, 721-733, doi:10.1111/j.1365-2389.2010.01266.x.

30. Walker, S.M.; Desanker, P.V. The impact of land use on soil carbon in Miombo Woodlands of Malawi. Forest Ecology and Management 2004, 203, 345-360, doi:10.1016/j.foreco.2004.08.004.

31. Romeu-Dalmau, C.; Gasparatos, A.; Maltitz, G. von; Graham, A.; Almagro-Garcia, J.; Wilebore, B.; Willis, K.J. Impacts of land use change due to biofuel crops on climate regulation services: Five case studies in Malawi, Mozambique and Swaziland. Biomass and Bioenergy 2018, 114, 30-40, doi:10.1016/j.biombioe.2016.05.011.

32. Winowiecki, L.; Vågen, T.-G.; Huising, J. Effects of land cover on ecosystem services in Tanzania: A spatial assessment of soil organic carbon. Geoderma 2016, 263, 274-283, doi:10.1016/j.geoderma.2015.03.010.

33. Muposhi, V.K.; Ndlovu, M.; Gandiwa, E.; Muvengwi, J.; Muboko, N. Vegetation dynamics prior to wildlife reintroductions in southern umfurudzi park, Zimbabwe. J. Anim. Plant Sci., 2014, 24, 1680-1690.

34. Ando, K.; Shinjo, H.; Noro, Y.; Takenaka, S.; Miura, R.; Sokotela, S.B.; Funakawa, S. Short-term effects of fire intensity on soil organic matter and nutrient release after slash-and-burn in Eastern Province, Zambia. Soil Science and Plant Nutrition 2014, 60, 173-182, doi:10.1080/00380768.2014.883487. 
35. Ryan, C.M.; Williams, M.; Grace, J. Above- and belowground carbon stocks in a Miombo wooodland landscape of Mozambique. Biotropica 2011, 43, 423-432.

36. Shelukindo, H.B.; Semu, E.; Msanya, B.M.; Singh, B.R.; Munishi, P.K.t. Soil organic carbon stocks in the dominant soils of the Miombo woodland ecosystem of Kitonga Forest Reserve, Iringa, Tanzania. Int. J. Agric. Policy Res., 2014, 2, 167-177.

37. Jenkinson, D.S.; Meredith, J.; Kinyamario, J.I.; Warren, G.P.; Wong, M.T.F.; Harkness, D.D.; Bol, R.; Coleman, K. ESTIMATING NET PRIMARY PRODUCTION FROM MEASUREMENTS MADE ON SOIL ORGANIC MATTER. Ecology 1999, 80, 2762-2773, doi:10.1890/0012-9658(1999)080[2762:ENPPFM]2.0.CO;2.

38. Kutsch, W.L.; Merbold, L.; Ziegler, W.; Mukelabai, M.M.; Muchinda, M.; Kolle, O.; Scholes, R.J. The charcoal trap: Miombo forests and the energy needs of people. Carbon Balance Manag. 2011, 6, doi:10.1186/1750-0680-6-5.

39. Woollen, E.; Ryan, C.M.; Williams, M. Carbon Stocks in an African Woodland Landscape: Spatial Distributions and Scales of Variation. Ecosystems 2012, 15, 804-818, doi:10.1007/s10021-012-9547-x.

40. Dube, T.; Muchena, R.; Masocha, M.; Shoko, C. Estimating soil organic and aboveground woody carbon stock in a protected dry Miombo ecosystem, Zimbabwe: Landsat 8 OLI data applications. Physics and Chemistry of the Earth, Parts A/B/C 2018, 105, 154-160, doi:10.1016/j.pce.2018.03.007.

41. Mujuru, L.; Mureva, A.; Velthorst, E.J.; Hoosbeek, M.R. Land use and management effects on soil organic matter fractions in Rhodic Ferralsols and Haplic Arenosols in Bindura and Shamva districts of Zimbabwe. Geoderma 2013, 209-210, 262-272, doi:10.1016/j.geoderma.2013.06.025.

42. Stromgaard, P. Biomass, growth, and burning of woodland in a shifting cultivation area of South Central Africa. Forest Ecology and Management 1985, 12, 163-178, doi:10.1016/0378-1127(85)90089-1.

43. Ando, K.; Shinjo, H.; Kuramitsu, H.; Miura, R.; Sokotela, S.; Funakawa, S. Effects of cropping and short-natural fallow rotation on soil organic carbon in the Eastern Province of Zambia. Agriculture, Ecosystems \& Environment 2014, 196, 34-41, doi:10.1016/j.agee.2014.06.012.

44. Shirima, D.D.; Munishi, P.K.t.; Lewis, S.L.; Burgess, N.D.; Marshall, A.R.; Balmford, A.; Swetnam, R.D.; Zahabu, E.M. Carbon storage, structure and composition of miombo woodlands in Tanzania's Eastern Arc Mountains. African Journal of Ecology 2011, 49, 332-342.

45. Muposhi, V.K.; Chademana, T.C.; Gandiwa, E.; Muboko, N. Edge effects: impact of anthropogenic activities on vegetation structure and diversity in western Umfurudzi Park, Zimbabwe. Afr. J. Ecol. 2016, 54, 450-459. 